Proceedings of the Conference "Integrating Engineering Education and Humanities for

Global Intercultural Perspectives"

IEEHGIP 2022: Integrating Engineering Education and Humanities for Global Intercultural

Perspectives pp 138-148| Cite as

\title{
Adopting the Discovery Method to Develop Linguistic Competence Among International Students: Experience from Russia and Belarus
}

- Authors

- Authors and affiliations

- Ksenia A. Girfanova

- Liudmila V. Anufryienka

- Alena V. Kavaliova

Conference paper

First Online: 07 May 2020

- 300Downloads

Part of the Lecture Notes in Networks and Systems book series (LNNS, volume 131)

\section{Abstract}

The article addresses linguistic competence and the importance of its formation for academic and professional purposes. It also posits that linguistic competence is an important part of the communicative one.

The Discovery Method is proposed as a privileged tool when teaching international students to apply the norms and rules established in a language. In this article the authors give a number of reasons why this method should be used, and how to apply it during English teaching process in a class.

The research is based on the data collected during English and Russian classes and is conducted in three universities by means of observation, discussion, interview, and questionnaire.

The article proposes a set of 3 tables of descriptors to assess the student's linguistic competence in three types of class activities: translation, writing, and reading. It also introduces a framework of exercises for teachers who wish to use the Discovery Method. 
Theoretical ground has been set for further research, focusing on the results of using the Discovery Method for linguistic competence formation.

\section{Keywords}

Linguistic Competence Discovery Method English and Russian as

a Foreign Language Communicative approach Criteria of competence development

\section{References}

1. 1 .

McDonough, S.: Applied Linguistics in Language Education. MPG Books Ltd., London (2002) Google Scholar

2. 2.

Widdowson, H.G.: Defining Issues in English Language Teaching. Oxford University Press, Oxford (2003) Google Scholar

3. 3.

Thoughtco.com. https:// www.thoughtco.com/ what-is-linguistic-competence-1691123. Accessed 21 Dec 2019

4. 4 .

Litvinko, F.M.: Kommunikativnaya kompetenciya kak metodicheskoe ponyatie [Communicative Competence as a Methodological Concept]. Kommunikativnaya kompetenciya: principy, metody, priemy formirovaniya [Communicative Competence: Principles, Methods, Ways of Formation] 9, pp. 1-6 (2009). (in Russian)Google $\underline{\text { Scholar }}$

5. 5 .

Science-education.ru. https:// www.science-education.ru/ru/article/view?id=28244. Accessed 21 Oct 2019

6. 6 .

Iasj.net. https:// www.iasj.net/iasj?func=fulltext\&aId=79339. Accessed 19 Oct 2019

7. 7.

Tarango, J ., Machin-Mastromatteo, J.D.: The Role of Information Professionals in the Knowledge Economy. Chandos Publishing, Oxford (2017) Google Scholar

8. 8 .

Bergstrom, J.M., O’Brien, L.A.: Themes of Discovery. Educ. Leadersh. 58(7), 29- 33 (2001) Google Scholar 
Baker, W.: Discovery method and teaching-research. In: Czarnocha, B., Baker, W., Dias, O., Prabhu, V. (eds.) The Creative Enterprise of Mathematics Teaching Research, pp. 245- 252. Sense Publishers, Rotterdam (2016)CrossRefGoogle Scholar

10. 10.

J oolingen, W.: Cognitive tools for discovery learning. Int. J . Artif. Intell. Educ. 10, 385- 397 (1999) Google Scholar

Stokke, A.: What to do about Canada's declining math scores. https:// www.cdhowe.org/ sites/default/files/attachments/research papers/mix ed/ commentary 427.pdf. Accessed 20 Sept 2019

Bloom, B.: Taxonomy of Educational Objectives: Cognitive and Affective Domains. David McKay, New Year (1956) Google Scholar

Studwood.ru. https:// studwood.ru/ 1653514/informatika/ zaklyuchenie. Accessed 19 Sept 2019

Karavanova, N.B.: Chitaem i vse ponimaem: posobie po chteniju i razvitiju rechi dlia inostrancev, izuchajushih russkij [Read and Understand Everything: The Textbook on Reading and Developing the Speech for Foreigners who Study Russian Language]. Russian Language Courses, Moscow (2018). (in Russian)Google Scholar

Durga, S.S., Rao, C.S.: Developing students' writing skills in english - a process approach. J . Res. Scholars Prof. Engl. Lang. Teach. 6(2), 1- 5 (2018)Google Scholar

\section{Copyright information}

(C) Springer Nature Switzerland AG 2020

\section{About this paper}

\section{CrossMark}

\section{Cite this paper as:}

Girfanova K.A., Anufryienka L.V., Kavaliova A.V. (2020) Adopting the Discovery Method to Develop Linguistic Competence Among International Students:

Experience from Russia and Belarus. In: Anikina Z. (eds) Integrating Engineering Education and Humanities for Global Intercultural Perspectives. IEEHGIP 2022. Lecture Notes in Networks and Systems, vol 131. Springer, Cham. https://doi.org/10.1007/978-3-030-47415-7_15

- First Online07 May 2020 
- DOlhttps://doi.org/10.1007/978-3-030-47415-7_15

- Publisher NameSpringer, Cham

- $\quad$ Print ISBN978-3-030-47414-0

- Online ISBN978-3-030-47415-7

- eBook Packages Intelligent Technologies and RoboticsIntelligent Technologies and Robotics (R0)

- $\quad$ Reprints and Permissions 